\section{Slow road to cooperation}

\section{Munich}

DEsPITE the dramatic political changes in East Germany and the opening of the borders on 9 November, the widely expected increase in industrial and scientific contacts between the two German states is only slowly coming into view.

The West German Research Ministry (BMFT) announced last week that it expects there to be many more cooperative projects between the two German states. Perhaps as many as 20 new projects might be initiated by early next year, nearly a doubling of the current number. But financial and political hurdles must be overcome before such cooperation can flourish.

The new projects, ranging from surface science to data processing to continental deep drilling, were discussed at a meeting in October between representatives of the two states. Officials will meet early in 1990 to discuss the proposals put forward both by East Germany and by West German universities.

Ministry officials were especially optimistic that the Fraunhofer Institutes, which do applied research under contract to industry, might receive contracts from East German industrial combines.

BMFT officials say their hopes of brushing aside political obstacles to cooperation were strengthened by the October meeting, which took place in Wiesbaden, West Germany, the day after East German leader Erich Honecker was deposed.

The East German officials recognized the need for economic reform in their country and wanted to explore ways to use West German knowhow to achieve it, a spokesman for BMFT said. The previous tendency to put a speed limit on cooperation was no longer there, he said.

But contacts continue to be limited by East Germany's lack of money. In many cases, the inefficiency and poor management at many combines and state-run agencies is only now coming to light. Research contacts may have to take a back seat during the many years of rebuilding necessary. Until then, East Germany will look to the West for help.

Until now, BMFT has followed the West German government line of waiting for proof of political and economic reforms - including free elections and the introduction of a market-oriented economy - before volunteering Western money for East Germany. The spokesman said the planned visit of Chancellor Helmut Kohl to East Germany in midDecember is expected to clarify the situation.

In the meantime, other political and bureaucratic problems remain. Cooperation between the two German states has always been hindered by the status of

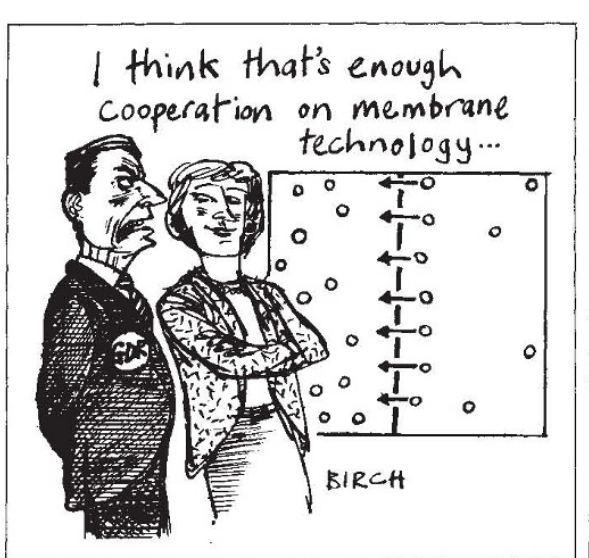

West Berlin, which East Germany refuses to recognize as a de facto part of West Germany. West Berlin is still officially administered by the Western Allies. West Germany insisted on the inclusion of West Berlin researchers in all cooperation agreements, which made negotiations difficult.

Technology transfer to East Germany could also be held up by the CoCom restrictions on high-technology exports, which remain in force despite the political changes in the Soviet bloc. The current agreement on scientific cooperation between the two German states, signed in Bonn in September 1987, includes few projects that involve high technology (see Nature 329, 192; 1987). Steven Dickman

\section{MAX PLANCK SOCIETY \\ Expanding contacts Munich}

The Max Planck Society expects to expand its contacts with the East German Academy of Sciences beginning early next year.

During a visit of academy president Werner Scheler to Munich in mid-October, the two organizations agreed to work out a 'framework agreement' for future links between their organizations. The agreement would make it easier for researchers on one side to invite and collaborate with their counterparts in the other country and would lay down the financial terms for the visits.

A spokesman for the Max Planck Society said that of 384 official guests last year from the Soviet bloc and China, not a single one came from East Germany.

The Max Planck Society has 62 institutes and an annual budget of DM 1,240 million ( $\$ 670$ million). It has 13,000 employees, who do primarily basic research. The Academy of Sciences of the German Democratic Republic, modelled on the Soviet Academy of Sciences, has 70 institutes and 23,000 employees. Its annual budget of 1,000 million East German marks is spent both on basic research and applied research for industrial combines (Kombinate).

Steven Dickman

\section{Research still a priority \\ Berlin}

STREeT demonstrations, shouted slogans, and the triumphant return en masse of East Germans to West Berlin after a 28-year absence give the impression that life in East Germany is one big party. It only adds to the elation that the East German government appeared so receptive to the changes proposed by opposition groups.

But the party is coming to an end, as the opposition, led by New Forum, must make its own proposals for the construction of a new society on the ruins of the old

The state of the East German economy is more worrying than is often supposed. Much of East German industry faces collapse after decades of neglect. Even such staples as energy for home heating could be interrupted, with serious consequences.

Against this backdrop, the future of research institutes may seem trivial, but New Forum members are convinced that research, both basic and applied, is central to the future of the economy. If research is not protected, they warn, "the next crisis is already programmed".

New Forum emerged earlier this year when the 18-year rule of Erich Honecker was seen to be running out of time. "A change was in the air", says physicist Sebastian Pflugbeil, one of the few dozen founders.

At the outset banned, New Forum has become one of the most popular political groups in East Germany, although it clings to its identity as a "citizens' initiative" and has resisted pressure to become a political party. It has been the catalyst for many of the street demonstrations of recent weeks.

New Forum is not so much interested in reforms within the government party as with the rot that reaches much further down in all areas of society, including science. "Too many department heads have prevented their subordinates from doing effective research work; they must be replaced", says Pflugbeil, who works at the Academy of Science's Central Institute for Heart and Circulation Research in Berlin-Buch. He says that important positions there have been filled on a "false selection principle", based on ideology rather than achievement, and that the problem is more general.

"But I don't know where to get competent people to replace them", he continues, "or what to do with them when they have been sent home". East Germany already has a labour shortage because of all the refugees who have fled to West Germany, estimated on 26 November at 283,696 this year alone.

Allotting research funds transparently is another top priority. Even research directors do not know how much has been spent in their respective areas across East Germany. Academy and university funds in many fields have not been totalled to give an overview of 
research spending.

The present crisis may tempt the government to cut back on all research, which Jens Reich, a molecular biologist and member of New Forum, believes would be disastrous by prompting East German scientists to sell their services to the highest bidder. West Germany, the most likely outlet, might then come to rely on East German laboratories for routine or labour-intensive measurements. Already it is reported that East German medical patients have been offered to West German pharmaceutical companies for tests of new drugs.

Would East German researchers really sell out in ways like this if support started to dry up? Reich says, "I only know the scientific community here as frustrated and cowardly, so I am not sure how alert they are to this danger". Reich also sees danger in the "robberbaron" mentality that might take over if East German researchers were forced to compete for the little hard currency available.

New Forum is only slowly learning of others' efforts to restructure institutes. Groups of researchers seem to be meeting independently in living rooms across East Germany to discuss restructuring of their institutes. Eventually, New Forum, may coordinate these discussions, but separate groups seem to be thinking along similar lines.

Dietrich Koch, a specialist in artificial intelligence, has led a group planning a new structure for the Central Institute for Cybernetics and Information Processing at which he works. The plan, put forward on 30 October, is already being put into practice in the vacuum formed by the abolition last week of the Academy statute, the legal basis for the organization of institutes within the academy.

Instead, there is now an institute council to give researchers and technical personnel a say in important decisions previously made by the director or handed down from above, including the choice of topics for investigation and allocation of funds between them.

The weak point in the plan, Koch admits, is the future role of the director. If a director should refuse to accept a diminished role or to cooperate with the changes, there could be trouble. Fortunately, Koch says, the director of his own institute has played a leading part in the reforms. "We all thought he was much more calcified than he has turned out to be."

Koch also proposes that the guaranteed funds that all institutes are used to receiving should be eliminated, a change that may meet resistance from researchers. "The old system stifles creativity", he says, since department heads considered new projects proposed by underlings too risky.

Koch and the others even so agree that there must be a basis of socialism in any new structure of East German research. They say that their views enjoy broad support from researchers of all ages. "If we don't do something different from the West, we might as well all go to West Germany.

Steven Dickman

\section{Rumours of trouble denied}

\section{Washington}

Although the House of Representatives and the Senate finally agreed this year to authorize $\$ 225$ million to start building the Superconducting Super Collider (SSC), the $20 \mathrm{TeV}, 53$-mile circumference proton-proton accelerator, the highenergy physics community and interested politicians still evidently feel that the project's future is somewhat precarious. This nervousness last week led Representative Joe Barton (Republican-Texas), whose district includes Waxahachie, the proposed site of the SSC, to pay a visit to the Department of Energy (DoE) and hold a press briefing with the aim of calming fears of cost over-runs and technical difficulties hinted at in an otherwise insubstantial story in the Washington Post.

The gist of the newspaper story was that SSC director Roy Schwitters had asked the DoE for as much as $\$ 2,000$ million over the estimated cost of $\$ 5,900$ million to modify and augment the SSC in order to overcome technical troubles with the prototype superconducting magnets. There was also a suggestion that SSC physicists wanted to redesign the injector for the main accelerator ring: in the conceptual SSC design, now four years old, the injector was to feed protons at $1 \mathrm{TeV}$ into the main ring, which would boost them to $20 \mathrm{TeV}$; now, according to the Washington Post, the plan was to raise the injection energy to $2 \mathrm{TeV}$, easing the task of the main ring magnets.

But Barton, after talking to Schwitters and Deputy Energy Secretary W. Henson Moore, said flatly that there had been no request for extra money, and that a change in the injection energy was merely one of a number of ideas that were being considered in adapting the conceptual design to a final design specific to the Waxahachie site. Barton added that there was also a possibility of reducing the length of the main ring magnets from 17 metres to 12 , but that this was being considered, among other reasons, because shorter magnets would be easier to install.

Little of this is in fact new. Even when the conceptual design was released, there was talk of changing the injector energy to 2 TeV. SSC spokesman Russ Wylie said that this option had received extra support from computer simulations which indicated that a higher injection energy would improve beam quality. And he added that although the first prototypes of the main ring magnets did not produce a magnetic field of sufficiently high uniformity, later models were doing well. He emphasized that the magnet design is still changeable, and will be made final only in a year or two, after collaborative work with the companies that will mass-produce the thousands of magnets needed.

The \$225 million authorized for this financial year is being partially held back by the DoE until it has approved sitespecific SSC design, which Schwitters hopes will be ready by the end of the year. Both Wylie and a DoE spokesman agreed that the advertized cost ceiling of $\$ 5,900$ million was a solid one, and that changes in the injector, for example, are unlikely to win DoE approval, no matter how good the technical arguments, if they increase the cost.

Although, according to Barton, the Post story set off no political fires, he and others were evidently anxious to stamp out the smouldering rumours before they had a chance to flare up.

But the incident did bring out from several quarters official declarations that the SSC will come in at or below budget, statements which may haunt Schwitters and others should the design changes now being pondered belie more serious problems than have been publicly admitted.

David LIndley LASER TECHNOLOGY

\section{Tamper-proof passport on the way}

\section{Sydney}

Australia is about to begin marketing a counterfeit-proof passport. The Department of Foreign Affairs and Trade has developed a laser-printing technique and a special plastic laminate to make what they claim is the world's finest tamper-proof document.

In a conventional laminated passport, the photograph is attached to a page and sealed on by a plastic screen, but the screen can be removed and a new photograph inserted. In the new technique, which works only in black and white, photographic images and other details are printed by laser onto an adhesive reversed- image film, which is then ingrained into the glue of the passport laminate.

The Australian government, according to director of passports Ted Radclyffe, has taken out a provisional patent on the process, and a licensing agreement has been signed with the $3 \mathrm{M}$ company and Gestetner, developers of the laser printer. Radclyffe says that the United States, New Zealand and Singapore are likely to be early investors and that with expanding markets worldwide for other security printing applications, such as drivers' licenses and identity cards, the technique is "likely to make Australia a lot of money".

Tania Ewing 